\title{
Ethnobotany and Traditional Knowledge of Acanthaceae in Peninsular Malaysia: A Review
}

\author{
Siti Maisarah Zakaria, Che Nurul Aini Che Amri*, Rozilawati Shahari
}

Siti Maisarah Zakaria, Che Nurul Aini Che Amri*, Rozilawati Shahari

Department of Plant Science, Kulliyyah of Science, International Islamic University of Malaysia, Jalan Sultan Ahmad Shah, 25200 Kuantan, Pahang, MALAYSIA

\section{Correspondence}

\section{Che Nurul Aini Che Amri}

Department of Plant Science, Kulliyyah of Science, International Islamic University of Malaysia, Jalan Sultan Ahmad Shah, 25200 Kuantan, Pahang, MALAYSIA

Phone no: 09-5705157; 013-3308024

E-mail: chenurulainicheamri@iium.edu.my History

- Submission Date: 28-06-2020:

- Review completed: 19-07-2020;

- Accepted Date: 05-08-2020

DOI : $10.5530 /$ pj.2020.12.203

Article Available online http://www.phcogj.com/v12/i6

\section{Copyright}

(c) 2020 Phcogi.Com. This is an openaccess article distributed under the terms of the Creative Commons Attribution 4.0 International license.

\section{ABSTRACT}

Plants are considered as a great source of various herbal medicines which are been useful in the treatment of various ailments and diseases. A great contribution of plant-based materials in the pharmaceutical field results in the growing interest on the exploitation of indigenous medicinal plants to make a potential medicine. Several potent plant families are broadly investigated throughout the world including the family of Acanthaceae. Acanthaceae is a large pantropical family of flowering plants comprised of approximately 240 genera and 3250 species in the world. In Peninsular Malaysia, Acanthaceae is one of the families with the largest number of genera and species by which 29 genera and 158 species are respectively recorded. This study thereby deals with the review of information on the ethnobotanical significance of medicinal plants belong to Acanthaceae. This review covers informative data on medicinal plants, its uses and part used based on three tribal groups of indigenous people, Malay villagers and local market traders in Peninsular Malaysia. From the review, Acanthaceae possesses a huge contribution to the ethnobotanical part especially to treat certain diseases. The ethnobotanical data has also served a great contribution to the conservation and sustainability of natural resources. By keeping this point, this present review on ethnobotany and traditional knowledge of Acanthaceae is expected to give benefits and considered a good starting point for future works on the pharmaceutical field, especially for Peninsular Malaysia.

Key words: Acanthaceae, Ethnobotany, Medicinal plants, Traditional knowledge.

\section{INTRODUCTION}

\section{General description of medicinal plants}

Plants play an important role in human life whether for the sake of food source, shelter, spiritual or medicinal purposes. Undoubtedly, plants possess the basis of traditional medicines throughout the world for thousands of years which continuously provides new remedies for mankind. To be surprised, $25 \%$ of ingredients in the prescribed modern medicine are directly or indirectly derived from the higher plants. ${ }^{1,2}$ Also, it is reported that up to $80 \%$ of the world's population in the developing world relies on herbal medicinal products. ${ }^{3}$ It is significant to mention that the rising demand in medicinal plants led to the increasing pressure on the wild plant population. This later on resulted in over-harvesting of medicinal plants from the wild population as well as illegally selling of medicinal plants due to less control and monitoring. ${ }^{4}$ Apart from that, a great contribution of medicinal plants on herbal industries caused the increasing demands and price for these plants. It is reported that there is an increasing interest in the correct identification, taxonomic and medicinal properties of the indigenous medicinal plants. ${ }^{2}$ Hence, it is crucial to ensure the correct raw materials are harvested and supplied for the pharmacologists before the products have been released to the consumers.

Malaysia has an estimated number of 15, 000 species of vascular plants. ${ }^{5}$ From this number, Ridley's (1922-1926) successfully documented on 7, 183 species whereas Turner's (1997) catalog recorded 8, 198 species including ferns allies that specially focussed for Peninsular Malaysia. ${ }^{5}$ However, there is no comprehensive and up-todate checklist of plants specifically medicinal plants of Peninsular Malaysia. To be noticed, one of the families with the largest number of genera and species occurred in Acanthaceae family by which 29 genera and 158 species respectively recorded in Flora of Malaya. ${ }^{6}$ The higher number of species that occurred in Acanthaceae is expected to perform a great contribution to mankind in various aspects of life especially the medicinal part. This present review article thereby discusses the ethnobotanical part and traditional knowledge of medicinal plants that belong to Acanthaceae family which specifically used by indigenous people, Malay villagers and medicinal plants traders in Peninsular Malaysia. The medicinal plants together with their uses are reviewed accordingly throughout this article.

\section{Background of acanthaceae family}

Acanthaceae is recognized as a large pantropical family of herbs and shrubs which belong to the order Lamiales. ${ }^{7}$ Besides, Acanthaceae is a large and diverse pantropical family consisting of approximately 240 genera and 3250 species throughout the world. ${ }^{8}$ The four main regions of its distribution are Malaysia and Indonesia, Brazil, Africa and Central America with the largest genus recorded in the genus Justicia that comprised of 600 species approximately. ${ }^{9}$ The systematic position of Acanthaceae has been discussed relatively according to recent molecular 
studies, pollen morphology, corolla aestivation and other potentially informative morphological homologs. ${ }^{10}$

Previously, the recognition of four subfamilies of Acanthaceae are Nelsonioideae, Thunbergioideae, Mendoncioideae and Acanthoideae based on the retinacula characteristics. ${ }^{11}$ Later on, the genera that lack of retinacula fruits are excluded ${ }^{12}$ and therefore the Acanthaceae is divided into two groups which are; Acanthoideae and Ruellioideae. However, a new finding has classify Acanthaceae into three subfamilies which are; Nelsonioideae, Acanthoideae and Thunbergioideae. ${ }^{10}$ Surprisingly, it is reported that the genus Avicennia has a sister relationship with Acanthaceae. ${ }^{13}$ Later, a new finding agreed on the placement of Avicennioideae into Acanthaceae. ${ }^{14}$ This up-to-date of Acanthaceae classification thereby were supported in Angiosperm Phylogeny Website by which four subfamilies of Acanthaceae were discovered that comprised of Nelsonioideae, Thunbergioideae, Acanthoideae and Avicennioideae. ${ }^{15}$

\section{General characteristics of acanthaceae family}

The morphological characteristics of Acanthaceae are prostrate, erects or rarely climbing herbs, herbs, subshrubs, shrubs or rarely small trees usually with the occurrence of cystoliths. ${ }^{8,16,17}$ The cystolith however was absent in subfamily of Nelsonioideae, Thunbergioideae and subtribe of Acantheae. ${ }^{10}$ Leaves of plants belonging to Acanthaceae are simple, opposite, decussate, rarely whorled or in rosettes, estipulate and usually entire-margined. ${ }^{16,17,18}$ Branches in decussate, terete to angular in cross-section and nodes often are swollen, sometimes spinose with spines derived from reduced leaves. ${ }^{17}$ Flowers of Acanthaceae are hermaphrodite and usually in racemes, spikes or cymes with rarely solitary flowers and zygomorphic to actinomorphic bisexual flowers symmetry. ${ }^{16,17}$ Seeds are usually borne on hook-like retinacula which attached to septa of the capsule but sometimes retinacula lacking in Nelsonia, Ophiorrhiphyllon, Staurogyne and Thunbergia. ${ }^{17}$ Surface often covered with hygroscopic hairs (expand when moistened) and smooth or roughened..$^{16,17}$

\section{ETHNOBOTANY OF ACANTHACEAE}

\section{Medicinal plants used by indigenous people}

The term ethnobotany was first introduced by American botanist, John Harshberger in the year 1896 which referred to "the study of plants use by humans". ${ }^{19}$ The field of ethnobotany not only focuses on medicinal plants, however, it is also covered on other products derived from natural sources such as food, coloring agents, fiber plants, fertilizers, building materials and so on..$^{20}$ In other means, ethnobotany is defined as the study of how people of particular regions and cultures utilize indigenous plants. ${ }^{18}$ In other words, ethnobotany helps to explore how plants have been used as food, shelter, medicine, clothing, hunting and traditional ceremonies. There are several sources of ethnobotanical study such as knowledge obtained from indigenous people, traditional medical practitioners or villagers and medicinal plant traders. In this present review article, the summary of medicinal plants belongs to Acanthaceae family that have been used by indigenous people, traditional medical practitioners, as well as medicinal plant traders have been reviewed accordingly.

Orang Asli or indigenous people is described as people with unique languages, knowledge systems as well as beliefs. ${ }^{21}$ In Peninsular Malaysia, Orang Asli is divided into three main tribal groups includes Semang (Negrito), Senoi and Proto Malay (Aboriginal Malay) which consists of 18 ethnics. Figure 1 below shows the classification of three main tribal groups and 18 ethnics of indigenous people in Peninsular Malaysia. ${ }^{22}$ Orang Asli has a special relation to their land and they believed that land is not a product and cannot be bought or sold. Instead, they hold that land is on loan to the people from God and it was their responsibility to take care of it. ${ }^{21}$ Present, the documentation of indigenous knowledge on medicinal plants is still ongoing in many parts of the world. The main reasons for these continuous efforts are because of poor transmission of knowledge to young generations, the potential use of this knowledge in pharmaceutical industries and the need to conserve a rare and highly demanded plant species in traditional medicine. ${ }^{23}$ On the bright side, these recorded indigenous medicinal plants represent such a useful starting point for further research especially on the discovery of a novel chemical compounds and potentially useful drugs. To be noticed, Acanthaceae is one of the plant families that contributes and plays a key role in the treatment of many diseases in native communities.

Indigenous people appreciate their land and utilized nature for their daily uses without giving harm to it. Since they lived deep in the forest and far from the facilities such as hospitals, they used the medicinal plants surround them to treat ailments and diseases. Sometimes, a medicinal plant species is reported to have multipurposes uses. ${ }^{24}$ For convenient purposes, a summary on medicinal plants belong to Acanthaceae family together with their uses that have been practiced

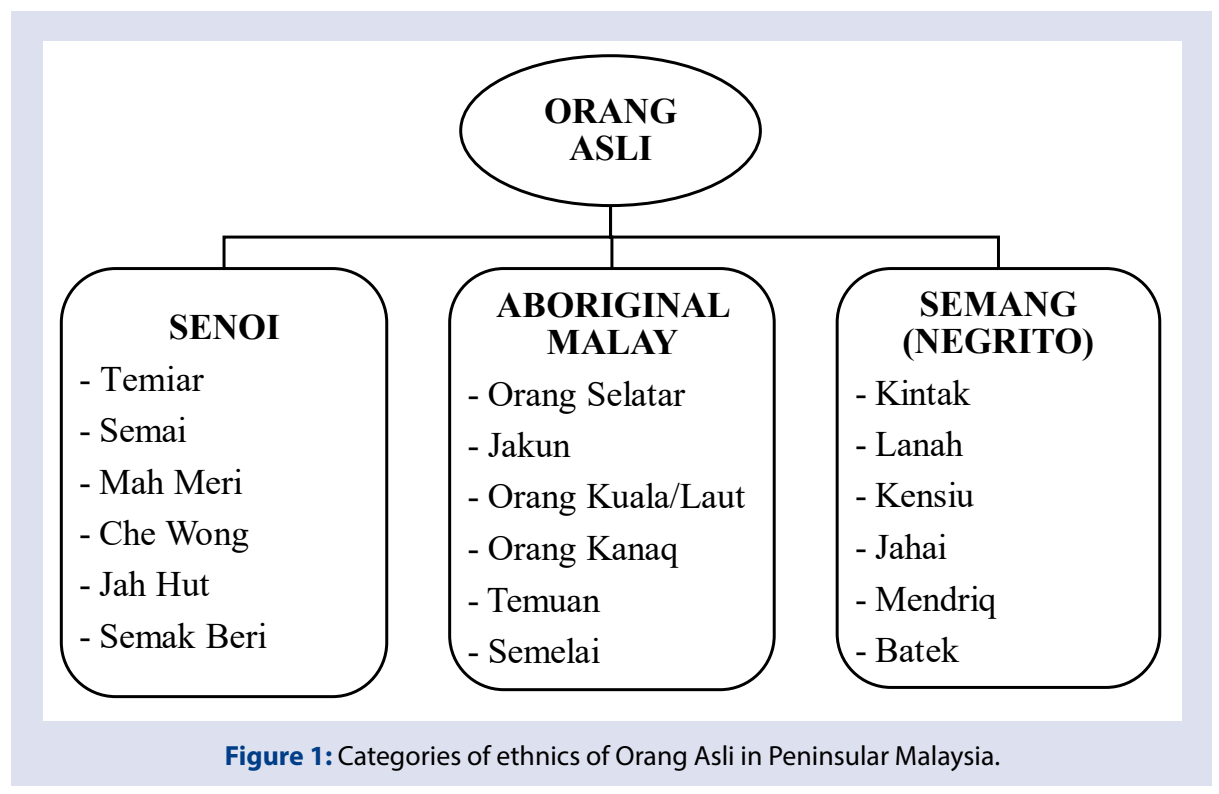


by Orang Asli in Peninsular Malaysia is presented in Table 1. These data are collected from several ethnobotanical surveys conducted amongst Orang Asli in Peninsular Malaysia following the standard methods of ethno-botanical enquiry or interviews. ${ }^{25-27}$

\section{Medicinal plants used by malay villagers and traders}

Apart from indigenous people, the ethnobotanical study has also engaged with the market survey which involved the interview or survey session with traders especially local market or traditional market traders. It is described that the local market is a type of open air-market and it may operate daily or one-day a week. ${ }^{28}$ Local markets is an important place or platform whereby the trading session among local people occurred and plant resource been sold at the local level. Besides, the market survey is often engaged in ethnobotanical studies by which this survey documented on the locally used herbal plants and their association with the traditional knowledge that have been practiced amongst the traders. ${ }^{4}$ To be noted, the ethnobotanical investigations on the local market have been less reported in Peninsular Malaysia. Despite that, it is more progressively investigated in other regions such as Indonesia ${ }^{29,30}$ and Brazil ${ }^{31}$. Interestingly, the documented plant species were not only used for medicinal purposes but also for various events such as marriage, baby shower and socializing. ${ }^{4}$

Furthermore, the ethnobotanical part has also covered on the folk botanical survey conducted amongst Malay villagers. It is believed that different localities of Malay villagers have different practices in utilizing the natural products. It is explained that the medicinal plants serve as an alternative to treat ailments whenever modern medicines are high-cost and difficult to obtain or there is not yet discovered modern drug to treat the diseases. ${ }^{32}$ By keeping this point, the contribution of traditional knowledge that has been practiced by Malay villagers is a good platform for the researcher to produce potentially new medicine. Apart, the informative data obtained from the ethnobotanical survey is important for the conservation and sustainable purposes. The information on medicinal plants usually obtained through general conservation with adult villagers, local healers and herbalists during the research visit. ${ }^{23,33,34}$ Besides, the target group of this study has also include traditional birth attendants, house wives, farmers and any other person who practised or used medicinal plants. ${ }^{35}$ The plant parts that commonly used are roots and leaves. However, it is significant to notice that the usage of leaves is less destructive when compared to roots and whole plants. ${ }^{32}$ This present study thereby summarized the medicinal plants recorded based on ethnobotanical studies amongst local market traders and Malay villagers in Peninsular Malaysia as in Table 2.

\section{TOXICITY OF MEDICINAL PLANTS CONCERN}

Upon the utilization of traditional medicinal plants, a few things need to be concerned including the toxicity of the medicinal plants used. It is believed that traditional practitioners possess knowledge of the quantity or dosage of the medicinal plants used throughout the treatment procedures. The ethnomedicinal data obtained from the traditional practitioners exactly gave insight about the toxicity of the herbal plants that have been practiced by the communities. ${ }^{35}$ Basically, people claimed that no toxic effect occurred when using the traditional herbal, but a few reports showed that it might be toxic if taken in excess or the case of wrong medications. ${ }^{35,36}$ Hence, the knowledge and information on medicinal plants' dosage are considered a good starting point for the pharmacologists to conduct more research on the traditional medicinal plants and their toxicity. The future works regarding the medicinal plants' dosage and toxicity are really helpful for the production of new drugs and medicines that later might benefit all mankind.

Table 1: Summary of medicinal plants according to tribal groups.

\begin{tabular}{|c|c|c|c|}
\hline $\begin{array}{l}\text { Scientific } \\
\text { names }\end{array}$ & Common names & Uses and part used & Study done by \\
\hline \multicolumn{4}{|c|}{ Proto Malay Tribe (Ayer Hitam Forest, Selangor) } \\
\hline \multirow{3}{*}{ Asystasia gangetica (L.) T.Anderson } & & Juice from leaves for eye treatment & \multirow{5}{*}{$\begin{array}{l}\text { Faridah-Hanum and Nurul-Huda, } \\
\qquad 1999\end{array}$} \\
\hline & Ara songsang & $\begin{array}{c}\text { Leaves chewed raw and applied externally to } \\
\text { wound }\end{array}$ & \\
\hline & & $\begin{array}{l}\text { Leaves mixed with 'paku merah' to relieve pain } \\
\text { inside bone }\end{array}$ & \\
\hline \multirow[t]{2}{*}{ Justicia gendarussa Burm. f. } & \multirow[t]{2}{*}{ Gandarusa } & $\begin{array}{l}\text { Leaves pounded with lemon for deworming and } \\
\text { stomach ache }\end{array}$ & \\
\hline & & Pounded roots for mouth during fits & \\
\hline \multicolumn{4}{|c|}{ Semang tribe (Kampung Bawong, Perak) } \\
\hline Barleria lupulina Lindl & Penawar seribu bisa & Fresh leaves are used to remove warts & \multirow{5}{*}{ Samuel et al., 2010} \\
\hline Barleria prionitis Linn. & Hempedu landak & $\begin{array}{l}\text { Leaves are crushed and made into paste and } \\
\text { applied over the inflamed area }\end{array}$ & \\
\hline Dipteracanthus repens (L.) Hassk. & Deras malam & $\begin{array}{l}\text { Powder of dried leaves is mixed in warm water } \\
\text { and drink to remove kidney stones }\end{array}$ & \\
\hline Eranthemum borneense Hook $\mathrm{f}$. & Sangsangkaruk & Paste of leaves is applied to treat muscle cramps & \\
\hline Strobilanthes crispus Blume & Bayam karang & $\begin{array}{l}\text { Fresh leaves are masticated and swallowed as } \\
\text { such to enhance the immune system }\end{array}$ & \\
\hline \multicolumn{4}{|c|}{ Senoi Tribe (Kampung Pos Panderas, Pahang) } \\
\hline Peristrophe acuminate Nees. & Pokok pengubat luka & $\begin{array}{l}\text { Pounded leaves applied topically on abrasions, } \\
\text { cuts and wounds }\end{array}$ & \multirow{4}{*}{ Ong et al., 2012} \\
\hline Chroesthes longifolia (Wight) Hansen & Pokok peluruh darah & Root decoction taken orally as an abortifacient & \\
\hline Lepidagathis incurva Buch.-Ham. & Sawi bangkok & $\begin{array}{l}\text { Pounded leaves mixed with kerosene applied } \\
\text { topically on shingles }\end{array}$ & \\
\hline Justicia betonica $\mathrm{L}$. & Bukau sepatah & Pounded leaves applied topically on sprains & \\
\hline $\begin{array}{l}\text { Pseuderanthemum crenulatum (L.) } \\
\text { (Lindl.) Radlk. }\end{array}$ & Seemelet & $\begin{array}{l}\text { Crushed the leaves and applied on external part } \\
\text { (two to four times daily) }\end{array}$ & Lin, 2005 \\
\hline
\end{tabular}


Table 2: Summary of medicinal plants used by Malay villagers and Traders.

\begin{tabular}{|c|c|c|c|}
\hline $\begin{array}{l}\text { Scientific } \\
\text { Names }\end{array}$ & $\begin{array}{l}\text { Common } \\
\text { Names }\end{array}$ & $\begin{array}{l}\text { Uses and } \\
\text { Part Used }\end{array}$ & Study done by \\
\hline \multicolumn{4}{|c|}{ Local Market Traders (Batu Pahat, Johor) } \\
\hline Strobilanthes crispa & Pecah beling or kaca & A decoction of leaves has been used to treat kidney stones & \multirow{3}{*}{ Adiba and Fatimah, 2018} \\
\hline $\begin{array}{l}\text { Andrographis paniculata (Burm.f.) } \\
\text { Nees }\end{array}$ & Hempedu bumi & $\begin{array}{l}\text { A decoction of leaves has been used to treat blood pressure } \\
\text { and diabetes }\end{array}$ & \\
\hline Asystasia gangetica & Rumput Israel & The squeezed of its leaves applied to the wound area & \\
\hline \multicolumn{4}{|c|}{ Malay Villagers (Kampung Tanjung Sabtu, Terengganu) } \\
\hline Asystasia coromandeliana Nees & Rumput Israel & A decoction of the whole plant taken orally to treat Dysuria & \multirow[b]{2}{*}{ Ong et al., 2011} \\
\hline $\begin{array}{l}\text { Andrographis paniculata (Burm.f.) } \\
\text { Wall. ex Nees }\end{array}$ & Hempedu bumi & $\begin{array}{l}\text { Decoction or infusion of the whole plant taken orally to } \\
\text { treat hypertension, diabetes and fever }\end{array}$ & \\
\hline \multicolumn{4}{|c|}{ Malay Villagers (Kampung Mak Kemas, Terengganu) } \\
\hline \multirow[t]{4}{*}{ Andrographis paniculata } & Hempedu bumi & $\begin{array}{c}\text { Infusion is taken orally to treat hypertension and fever } \\
\text { Decoction with Orthosipon aristatus taken orally to treat } \\
\text { diabetes }\end{array}$ & \multirow{6}{*}{ Ong et al., 2011} \\
\hline & & $\begin{array}{l}\text { A decoction is taken orally to treat influenza, chest pain and } \\
\text { tonsillitis }\end{array}$ & \\
\hline & & $\begin{array}{l}\text { Poultice applied topically and taken orally to treat bites and } \\
\text { stings area }\end{array}$ & \\
\hline & & The leaves decoction is taken orally to treat constipation & \\
\hline Asystasia coromandeliana & Rumput Israel & Poultice applied topically at swelling, cuts or wounds area & \\
\hline & & Poultice with garlic applied topically to treat muscle cramps & \\
\hline Justicia gendarussa & Gandarussa hitam & Pounded with lime fruit, applied topically for flatulence & \\
\hline \multicolumn{4}{|c|}{ Malay Villagers (Terengganu) } \\
\hline Andrographis paniculata & Hempedu bumi & $\begin{array}{c}\text { Maceration of roots, leaves and bark used to treat diabetes, } \\
\text { hypertension and fever }\end{array}$ & $\begin{array}{l}\text { Mahmoud-Dogara et al., } \\
2018\end{array}$ \\
\hline \multicolumn{4}{|c|}{ Malay Villagers (Masjid Ijok Village, Perak) } \\
\hline Andrographis paniculata & Hempedu bumi & $\begin{array}{c}\text { A decoction of the whole plant take orally to treat } \\
\text { hypertension }\end{array}$ & \\
\hline $\begin{array}{l}\text { Clinacanthus nutans (Burm F.) } \\
\text { Lindau }\end{array}$ & Belalai gajah & A decoction of leaves helps to treat gastro-intestinal & Raznan et al., 2015 \\
\hline Rhinacanthus communis (L.) Kurz & Ubat kurap & Leaves used to treat skin complaints & \\
\hline \multicolumn{4}{|c|}{ Malay Villagers (Pahang) } \\
\hline Gendarussa vulgaris & Gendarusa & $\begin{array}{l}\text { A decoction of leaves and roots are taken to relieve low } \\
\text { back pain }\end{array}$ & \multirow{5}{*}{$\begin{array}{l}\text { Mohd-Shukor and Nor- } \\
\text { Hafizah, } 2016\end{array}$} \\
\hline Andrographis paniculata & Hempedu tanah & $\begin{array}{l}\text { The decoction of leaves and roots are taken orally to treat } \\
\text { infection and ulcer }\end{array}$ & \\
\hline Staurogyne merguensis & Lemba hutan & $\begin{array}{l}\text { The entire plant is used for many medicinal purposes } \\
\text { especially in obstetrics and gynecology including treating } \\
\text { post-partum depression }\end{array}$ & \\
\hline \multirow[b]{2}{*}{ Lepidagathis longifolia } & \multirow[b]{2}{*}{ Peluruh } & $\begin{array}{l}\text { A water decoction of its roots has been known to be used } \\
\text { for terminating early pregnancy, treating infertility. }\end{array}$ & \\
\hline & & $\begin{array}{l}\text { A water decoction is also given to post-partum mother to } \\
\text { regain energy and strength after childbirth }\end{array}$ & \\
\hline Chroesthes longifolia & Peluruh darah & The roots decoction is taken orally as an abortifacient & \\
\hline
\end{tabular}

\section{CONCLUSION}

In summary, plants belong to Acanthaceae family have a great contribution towards the ethnobotanical and pharmacological parts. This present review article has presented the summary of Acanthaceae species that have been used by native communities, Malay villagers and local market traders in Peninsular Malaysia, specifically to treat certain ailments and diseases. Interestingly, these documented plant species together with their medicinal values could be a good starting point for future works in the pharmacological part. Therefore, it is important to have the correct identification of plants to avoid incorrect harvesting of plants and chemicals extracted which later might lead to the destruction of plant resources materials. In other words, it is important to ensure correct raw materials are been harvested and supplied for the pharmacology parts. Moreover, the role of the Forestry Department is really important in monitoring the regulation of forest harvesting. By keeping this point, the raw materials of indigenous medicinal plants can be conserved and utilized in the future. In other mean, people also will be aware and more appreciative on the heritage of indigenous knowledge. Therefore, it is proven that the ethnobotanical study could 
be one of the useful tools to document and record potential medicinal plants including Acanthaceae, especially in Peninsular Malaysia.

\section{ACKNOWLEDGEMENTS}

The authors wish to express their sense of appreciation to the Department of Plant Science, Kulliyyah of Science, International Islamic University of Malaysia, Kuantan, Pahang. Not to forget, special thanks dedicated to FRGS/1/2019/STG03/UIAM/03/2 (FRGS19-085-0694) for the financial support during this research period.

\section{REFERENCES}

1. Bandaranayake WM. Quality Control, Screening, Toxicity and Regulation of Herbal Drugs. Weinheim: Wiley-VCH GmbH \& Co. KGaA.; 2006.

2. Khan I, Jan SA, Shinwari ZK, Ali M, Khan Y, Kumar, T. Ethnobotany and medicinal uses of folklore medicinal plants belonging to family Acanthaceae: An updated review. Medcrave Online Journal of Biology and Medicine. 2017; 1(2):34-8.

3. Ekor M. The growing use of herbal medicines: issues relating to adverse reactions and challenges in monitoring safety. Ethnopharmacology. 2014;4:110.

4. Adiba AS, Fatimah SS, Editors. Edible and medicinal plants sold at selected local markets in Batu Pahat, Johor, Malaysia. Proceedings of the $5^{\text {th }}$ International Conference on Biological Science; 2018 August 15. Melville: AIP Publishing.

5. Saw LG, Chung RCK. The flora of Malaysia projects. Rodriguésia. 2018;66(4):94760.

6. Turner IM. A tropical flora summarized-a statistical analysis of the vascular plant diversity of Malaya. Flora. 1997;192:157-63.

7. Scotland RW, Sweere JA, Reeve PA, Olmstead RG. Higher level systematics of Acanthaceae determined by chloroplast DNA sequences. American Journal of Botany. 1995;82:266-75.

8. Wasshausen DC, Wood JRI. Acanthaceae of Bolivia. Washington: National Museum of Natural History; 2004.

9. Durkee L. Flora Costaricensis: Family Acanthaceae. Field Botany. 1996;1:1-87.

10. Scotland RW, Vollesen K. Classification of Acanthaceae. Kew Bulletin 5 . 2000;513-80

11. Lindau G. Acanthaceae. DIm. Engler A, Prantl, K. (pnyt..) Die natürlichen Pflanzenfamilien 4(3b). Leipzig: Verlag von Wilhem Engelmann; 1895.

12. Bremekamp CEB. Delimitation and subdivision of the Acanthaceae. Bulletin of the Botanical Survey of India. 1965;7:21-30.

13. Schwarzbach $A E, M c D a d e$ LA. Phylogenetic relationships of the mangrove family Avicenniaceae based on chloroplast and nuclear ribosomal DNA sequences. Systematic Botany. 2002;27(1):84-98.

14. Thorne RF, Reveal JL. An updated classification of the class magnoliopsida ("angiospermae). The Botanical Review. 2007;73(2):67-182.

15. Stevens PF [homepage on the Internet]. St. Louis: Missouri Botanical Garden, University of Missouri [updated 2020 February 25; cited 2020 April 5]. Available from: http://www.mobot.org/MOBOT/research/APweb/.

16. Vollesen K. Flora of Tropical East Africa: Acanthaceae. Kew: Royal Botanic Gardens; 2008.

17. Chia-Chi H, Yunfei D, Wood JRI, Daniel TF. Flora of China: Acanthaceae. Missouri: Missouri Botanical Garden Press; 2011.
18. Fongod AGN, Modjenpa NB, Veranso MC. Ethnobotany of Acanthaceae in the mount cameroon region. Journal of Medicinal Plants Research. 2013;7(38):2859-66.

19. Ghorbani A, Naghibi F, Mosaddegh M. Ethnobotany, ethnopharmacology and drug discovery. Iranian Journal of Pharmaceutical Sciences.2006;2(2):109-18.

20. Heinrich M, Barnes J, Gibbons S, Williamson EM. Fundamental pharmacognosy phytotherapy. London: Churchill Livingstone; 2004.

21. Masron T, Masami F, Norhasimah I. Orang Asli in Peninsular Malaysia: Population, Spatial Distribution and Socio-Economic Condition. Journal of Ritsumeikan Social Sciences and Humanities. 2013;75-115.

22. Jabatan Kemajuan Orang Asli, KementerianPembangunan Luar Bandar Suku kaum/bangsa. Kuala Lumpur (Malaysia): Jabatan Kemajuan Orang Asli; 2020.

23. Ong HC, Rosnaini MZ, Milow P. Traditional knowledge of medicinal plants among the Malay villagers in Kampung Mak Kemas, Terengganu, Malaysia. Ethno-medicine. 2011;5(3):175-85.

24. Faridah-Hanum, Nurul-Huda $H$. The use of medicinal plant species by the Temuan Tribe of Ayer Hitam Forest, Selangor, Peninsular Malaysia. Pertanika Journal Tropical Agriculture Science. 1999;22(2):85-94.

25. Samuel AJSJ, Kalusalingam A, Chellapan DK, Gopinath R, Radhamani S, Husain $A$, et al. Ethnomedical survey of plants used by the Orang Asli Kampung Bawong, Perak, West Malaysia. Journal of Ethnobiology and Ethno-medicine. 2010;1-6.

26. Ong HC, Faezah AW, Milow P. Medicinal plants used by the Jah Hut Orang Asli at Kampung Pos Panderas, Pahang, Malaysia. Ethno-Medicine. 2012;6(1):11-5.

27. Lin KW. Ethnobotanical study of medicinal plants used by the Jah Hut peoples in Malaysia. Indian Journal of Medical Sciences. 2005;59(4):156-61.

28. Albuquerque UP, Monteiro JM, Ramos MA, de Amorim EL, Alves RN. "Ethnobiological research in public markets," in Methods and Techniques in Ethnobiology and Ethnoecology. New York: Springer Protocols Handbooks Human Press; 2014.

29. Arman S. Diversity and trade of market fruits in West Kalimantan. NewYork: Oxford University Press; 1996.

30. Silalahi M, Nisyawati, Wahujo EB, Supriatna J, Mangunwardoyo W. The local knowledge of medicinal plants trader and diversity of medicinal plants in the Kabanjahe traditional market, North Sumatra, Indonesia. Journal Ethnopharmacol. 2015;175:432-43.

31. Monteiro JM, de Lima Araujo E, Amorim ELC, de Albuquerque UP. Local markets and medicinal plant commerce: a review with emphasis Brazil. Economic Botany. 2010;64(4):352-66.

32. Mohd-Raznan R, Milow P, Ong HC. Traditional knowledge of a practitioner in medicinal plants of Masjid ljok Village, Perak, Malaysia. Ethno-medicine. 2015;9(1):59-66.

33. Ong HC, Ruzalila BN, Milow P. Traditional knowledge of medicinal plants among the Malay villagers in Kampung Tanjung Sabtu, Terengganu, Malaysia. Journal of Traditional Knowledge. 2011;10(3):460-5

34. Mohd-Shukor N, Nor-Hafizah Z. Plants used for medicines by the indigenous Malay of Pahang, Malaysia. Medicinal Plants. 2016;8(2):142-50.

35. Mahmoud-Dogara AR, Abdul-Manaf A, Nur-Fatihah HN, Moneruzzaman MK, Nashriyah M. Traditional medicinal knowledge of Malays in Terengganu, Peninsular Malaysia. Malayan Nature Journal. 2018;70(3):349-64.

36. Sabran SF, Mohamed M, Abu Bakar MF. Ethnomedical knowledge of plants used for the treatment of tuberculosis in Johor, Malaysia. Evidence-Based Complementary and Alternative Medicine 2016. 2016;1-12. 
GRAPHICAL ABSTRACT

\section{ETHNOBOTANY AND TRADITIONAL KNOWLEDGE OF ACANTHACEAE IN PENINSULAR MALAYSIA: A REVIEW}

\section{ACANTHACEAE}
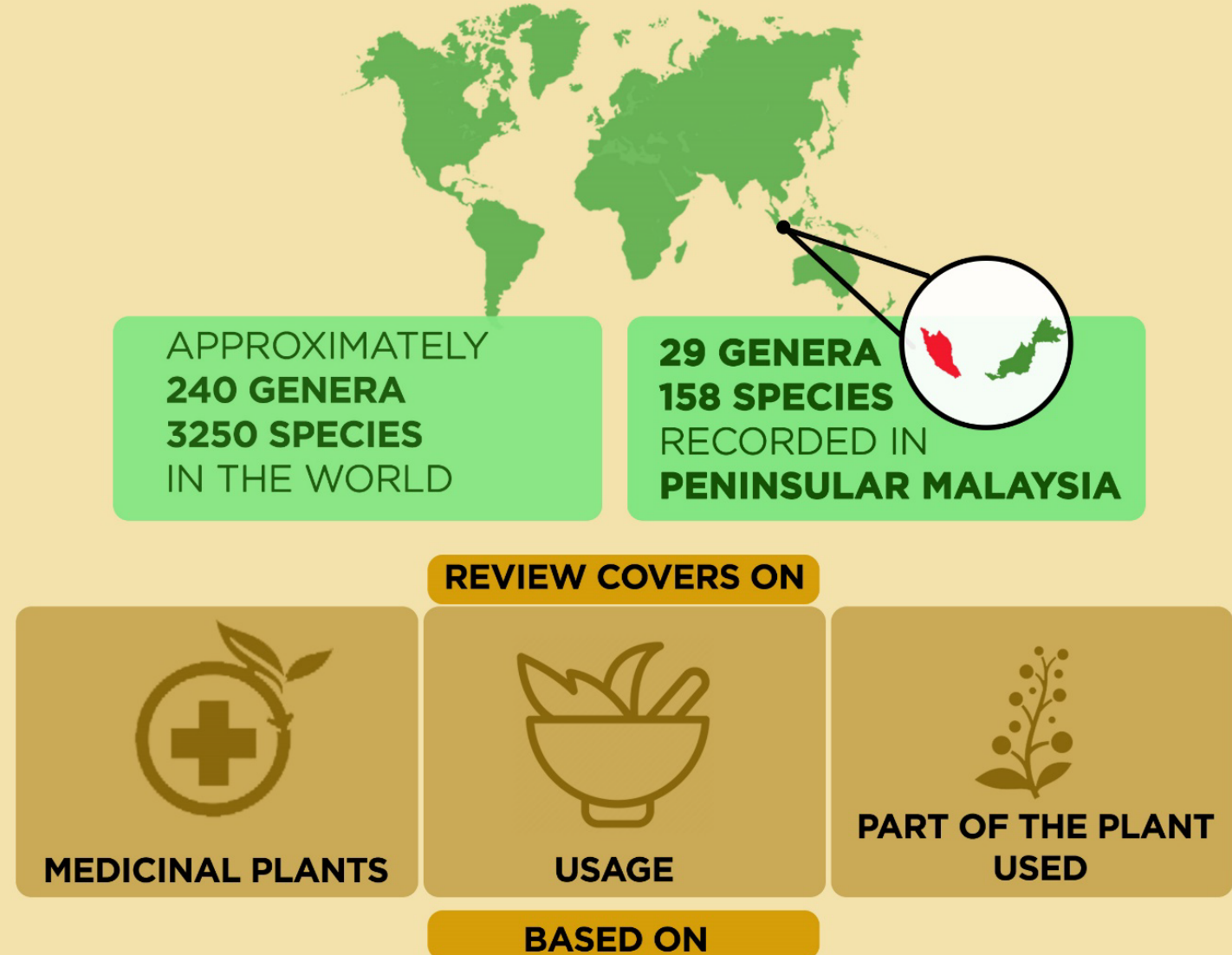

\section{BASED ON}

\section{THREE TRIBAL GROUPS OF INDIGENOUS PEOPLE}

2. MALAY VILLAGERS

3. LOCAL MARKET TRADERS IN PENINSULAR MALAYSIA

\section{ETHNOBOTANICAL DATA OF ACANTHACEAE}

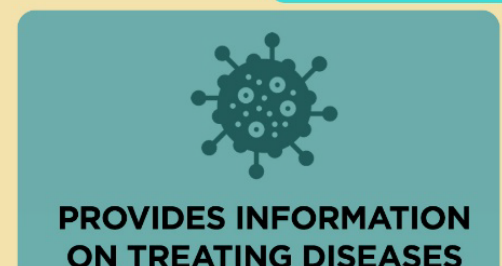

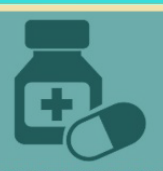

CONTRIBUTES TO THE PHARMACEUTICAL RESEARCH

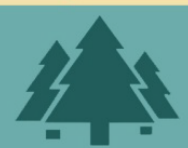

CONTRIBUTES TO THE CONSERVATION OF NATURAL RESOURCES 


\section{ABOUT AUTHORS}

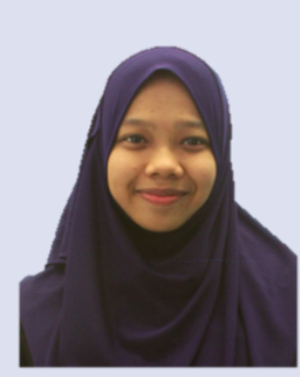

NAME: Siti Maisarah binti Zakaria

FACULTY: Department of Plant Science, Faculty of Science

ORGANIZATION: International Islamic University of Malaysia, Kuantan Campus, Jalan Sultan Ahmad Shah, Bandar Indera Mahkota, 25200 Kuantan Pahang

E-MAIL ADDRESS: sitimaisarahbintizakaria@gmail.com

POSITION/ROLE: Postgraduate Student

PROGRAMME: Master of Science (Bioscience)

RESEARCH PROJECTS:

In Progress

2019 - Systematic Characterization, Cytogenetic and Ethnobotanical Analyses of Acanthaceae in Peninsular Malaysia

NAME: Che Nurul Aini binti Che Amri

FACULTY: Department of Plant Science, Faculty of Science

ORGANIZATION: International Islamic University of Malaysia, Kuantan Campus, Jalan Sultan Ahmad Shah, Bandar Indera Mahkota, 25200 Kuantan Pahang

E-MAIL ADDRESS: chenurulainicheamri@iium.edu.my

POSITION/ROLE: Assistant Professor

AREA OF SPECIALISATION: Botany, Plant Anatomy, Plant Systematic

RESEARCH PROJECTS:

In Progress

2019 - Systematic Characterization, Cytogenetic and Ethnobotanical Analyses of Acanthaceae in Peninsular Malaysia

2019 - Taxonomic Study of Durio zibethinus in Jelebu N. Sembilan

2019 - Understanding Root Acclimation of Rice to Drought Stress through Cytogenetic Analysis and Its Interactions with Root Development and Architecture

2019 - Biofortication of Roots of Ficus carica with Plant Growth Promoting Rhizobacteria under Flooding Stress Environment

NAME: Rozilawati binti Shahari

FACULTY: Department of Plant Science, Faculty of Science

ORGANIZATION: International Islamic University of Malaysia, Kuantan Campus, Jalan Sultan Ahmad Shah, Bandar Indera Mahkota, 25200 Kuantan Pahang

E-MAIL ADDRESS: firdawila@iium.edu.my

POSITION/ROLE: Assistant Professor

AREA OF SPECIALISATION: Botany, Plant Diversity, Plant Taxonomy

RESEARCH PROJECTS:

In Progress

2019 - Genetics of Saline Water Submergence Tolerant Genotypes in the Malaysian Rice (Oryza sativa L.) Population

2019 - Systematic Characterization, Cytogenetic and Ethnobotanical Analyses of Acanthaceae in Peninsular Malaysia

2019 - A Framework for the Detection of Intelligent Source Code Plagiarism in Big Data using Word2vec Model

2019 - Taxonomic Study of Durio zibethinus in Jelebu N. Sembilan

2019 - Anti-vaxxer, Vaccination, WHO, Health Ministry, Standard Guideline, Health Journalism

Cite this article: Zakaria SM, Amri CNAC, Shahari R. Ethnobotany and Traditional Knowledge of Acanthaceae in Peninsular Malaysia: A Review. Pharmacogn J. 2020;12(6):1482-8. 